\title{
Lipid lowering by hydroalcoholic extracts of Amaranthus Caudatus L. induces regression of rabbits atherosclerotic lesions
}

\author{
Najmeh Kabiri ${ }^{*}$, Sedigheh Asgary ${ }^{2}$ and Mahbubeh Setorki ${ }^{3}$
}

\begin{abstract}
Background: The antihypercholesterolemic and antiatherogenic effect of hydroalcoholic extracts of Amaranthus caudatus $L($ A. caudatus). on regression of atherosclerosis in experimental rabbits maintained on a high cholesterol diet.

Methods: Twenty five rabbits were randomly divided into five groups of five each and treated 75 days as follows: Group I: normal diet(ND), Group II: Hypercholesterolemic diet (HCD) for 45 days; Group III: Hypercholesterolemic diet (HCD) for 75 days, Group IV and V: HCD for 45 days and then normal diet and normal diet + A. caudatus(150 $\mathrm{mg} \cdot \mathrm{kg}$ day) respectively for an additional 30 days(regression period). Blood samples were collected before (0 time) and after 45 days and 75 days of experimental diets for measurement of biochemical factors. The aortas were removed at the end of the study for assessment of atherosclerotic plaques.
\end{abstract}

Results: In regression period dietary use of A. caudatus in group V significantly decreased total cholesterol, LDLcholesterol, malondialdehyde, C-reactive protein while apolipoproteinA and HDL-cholesterol was significantly increased compared to group IV. The atherosclerotic area was significantly decreased in group V. Whereas, the animals that in regression period received only normal diet showed no regression but rather progression of atherosclerosis.

Conclusion: These results thus suggest that hydroalcoholic extracts of A. caudatus can reduce risk factors and cause regression of fatty lesons in aorta.

\section{Background}

Atherosclerosis is a dynamic and reversible process [1]. In animals fed a cholesterol-rich diet, lowering of plasma cholesterol levels promotes the regression of atherosclerotic lesions [1-3]. Evidence for atherosclerosis regression in humans has also been reported [4-6]. Although plasma lipid lowering is a major driving force, the mechanisms that promote lesion regression and stabilization are not clear [7]. Recent reports indicate that the reversal or regression of lesions can be achieved by aggressive lipid lowering or drug treatment [8,9]. Hypercholesterolemia induces oxidative stress, which is known to have adverse effects on the integrity of cells [10]. Antioxidants and hypolipidemic agents suppress

\footnotetext{
* Correspondence: kabiri_s97@yahoo.com

'Department of Biology, Faculty of Sciences, Isfahan University, Isfahan, Iran Full list of author information is available at the end of the article
}

the development of hypercholesterolemic atherosclerosis and induce regression of atherosclerosis. Suppresses the development of atherosclerosis is associated with decreases in oxidative stress and serum lipids [11-13].

Amaranthus Caudatus L.( A.Caudatus) which is synonym with Amaranthus Paniculatus $L$. was used in some studies. Grain and leaves of Amaranthus are utilized as food for human beings as well as for animals [14] and their nutritional value have been extensively studied [15]. Amaranthus leaves are an excellent source of protein, fiber, squalene, anthocyanins and tocotrienols [16-18]. Squalene is an intermediate in cholesterol biosynthesis and is found in humans under the skin and inside the adipose tissue [17]. The physiological effects of dietary flavonols are of current interest due to their in vitro anti-oxidative and anti-inflammatory activities [18]. It was recently shown positive effect of $A$. caudatus extract to decrease of cholesterol level, reduced serum
C Biomed Central

(C) 2011 Kabiri et al; licensee BioMed Central Ltd. This is an Open Access article distributed under the terms of the Creative Commons Attribution License (http://creativecommons.org/licenses/by/2.0), which permits unrestricted use, distribution, and reproduction in any medium, provided the original work is properly cited. 
lipid levels to atheromatous plaque formation [19,20]. Qureshi et al. (1991), shows that A. caudatus extracts contains tocotrienol and tocopherol [21]. Recently, it has shown that these two substance regulate cholesterol metabolism [22].

This study assessed the ability of Amaranthus Caudatus $L$. to reduce atheromatous plaque formation and also its ability to regress atheromatous lesions in hypercholesterolemic rabbits by analysing biochemical markers such as total cholesterol, triglyceride and LDLcholesterol, apolipoproteinB, malondialdehyde inflammatory markers such as $\mathrm{C}$-reactive protein (CRP) and lesion in the aorta by histochemical analysis.

\section{Material and Methods}

\section{Collection of plant material and extraction}

A. caudatus was collected from Isfahan Natural Resource Institute. They were identified by Dr. Lili Ghaemmaghami and a voucher specimen was deposited at the Herbarium of the Department of Biology, Faculty of Science and Isfahan University (voucher no. 13648). Aerial parts (stems, leaves and flowers) were dried for 10 days at room temperature it was extracted with $96 \%$ ethanol for 72 hours and then filtered, and concentrated by vacuum distillation. Solvent was evaporated under vacuum and crude extract was obtained as a dark reddish colour and kept in dark glass bottles at $4^{\circ} \mathrm{C}$ until use [23].

\section{Flavonoid and anthocyanines measurement}

Total flavonoids content was measured at $424 \mathrm{~nm}$, [24] and anthocyanins at $535 \mathrm{~nm}$ [25] using spectrophotometeric method.

\section{Animals and treatment}

Twenty five male New Zealand white rabbits with average body weight of 1.5-2 kg were purchased from Razi Institute, Teheran, Iran. The animals were housed in steel cages individually in a temperature and light controlled room for 2 weeks, and provided with Super Fosskorn Normal Rabbit Chow, purchased from Pasteur Institute of Iran.

\section{Regression studies}

The rabbits were divided into five groups of five rabbits each and for 75 days as follows.

- Group I: Fed with 100 g Normal diet daily (normal group). (75 days).

- Group II: Normal diet + cholesterol suspended in olive oil and added to the diet ( $1 \%$ of food content daily)Which is considered to be a high cholesterol diet (HCD) throughout the experiment (45 days).

- Group III: Normal diet + cholesterol suspended in olive oil and added to the diet ( $1 \%$ of food content daily)which is considered to be a high cholesterol diet (HCD) throughout the experiment (75 days).
For regression studies, 10 rabbits were a $1 \%$ cholesterol diet for 45 days and the rabbits were divided into two groups:

- Group IV: Normal diet for 30 days.

- Group V: Normal diet + A. caudatus extract(150 mg $\mathrm{kg}$ body weight daily) for 30 days. The study design is summarized in Figure 1.

Isfahan Cardiovascular Research Center Ethics Committee which is a member of office for human research protections, US department of health and human services, approved the present study, and the animals were handled according to guidelines of Isfahan University of Medical Sciences for Laboratory Animal Sciences for the care and use of laboratory animals.

\section{Measuring the biochemical factors}

Blood samples (from marginal ear vein) after 12 hours of fasting were collected before time 0,45 th \& 75 th days. The plasma was obtained by centrifuging the blood samples at $2000 \mathrm{rpm}$ for $15 \mathrm{~min}$ Total cholesterol (cho), Triglyceride(TG) and LDL-cholesterol (LDL-C) and HDL-cholesterol (HDL-C) were measured using special kits (DiaSys, Germany) which utilized the colorimetric method, in an autoanalyzer (Hitachi autoanalyzer, Hitachi Co., Tokyo). Concentrations of apolipoprotein A (apoA) and apolipoprotein $\mathrm{B}(\mathrm{apoB})$ were also measured using special kits (DiaSys, Germany) in an autoanalyzer (Hitachi autoanalyzer, Hitachi Co., Tokyo) according to the turbidimetric method; C-reactive protein (CRP) was also measured by rabbit CRP ELISA (Rapidbio, USA). We measured Ox-LDL by rabbit Ox-LDL ELISA (Rapidbio, USA). Malondialdehyde (MDA) was estimated by the double heating method of Draper and Hadley. The principle of the method is the spectrophotometric measurement of the color generated by the reaction of thiobarbituric acid with MDA.

All these factors were measured at the beginning, 30th and 60th day except for Ox-LDL which was checked only at 60th day. Atherosclerosis index was calculated according to the following formula: AI = LDL-C/HDL-C [26].

On the 75th day all the groups of animals, were sacrificed by rapid intracardiac pentobarbital injection for histopathological analyze.

\section{Histopathological analysis of liver and aorta}

At the end of experiment, the animals were killed, the aorta were removed and tissue sections $(5 \mu \mathrm{m})$ aorta fixed by immersion at room temperature in $10 \%$ formalin solution stained for fat deposits. For the histological examinations, paraffin-embedded tissue section of aorta were stained with hematoxylin-eosin (H\&E). The tissue samples were then examined and photographed under a light microscope for observation of structural abnormality. Chekanov scale was used for grading of atherosclerotic plaques 


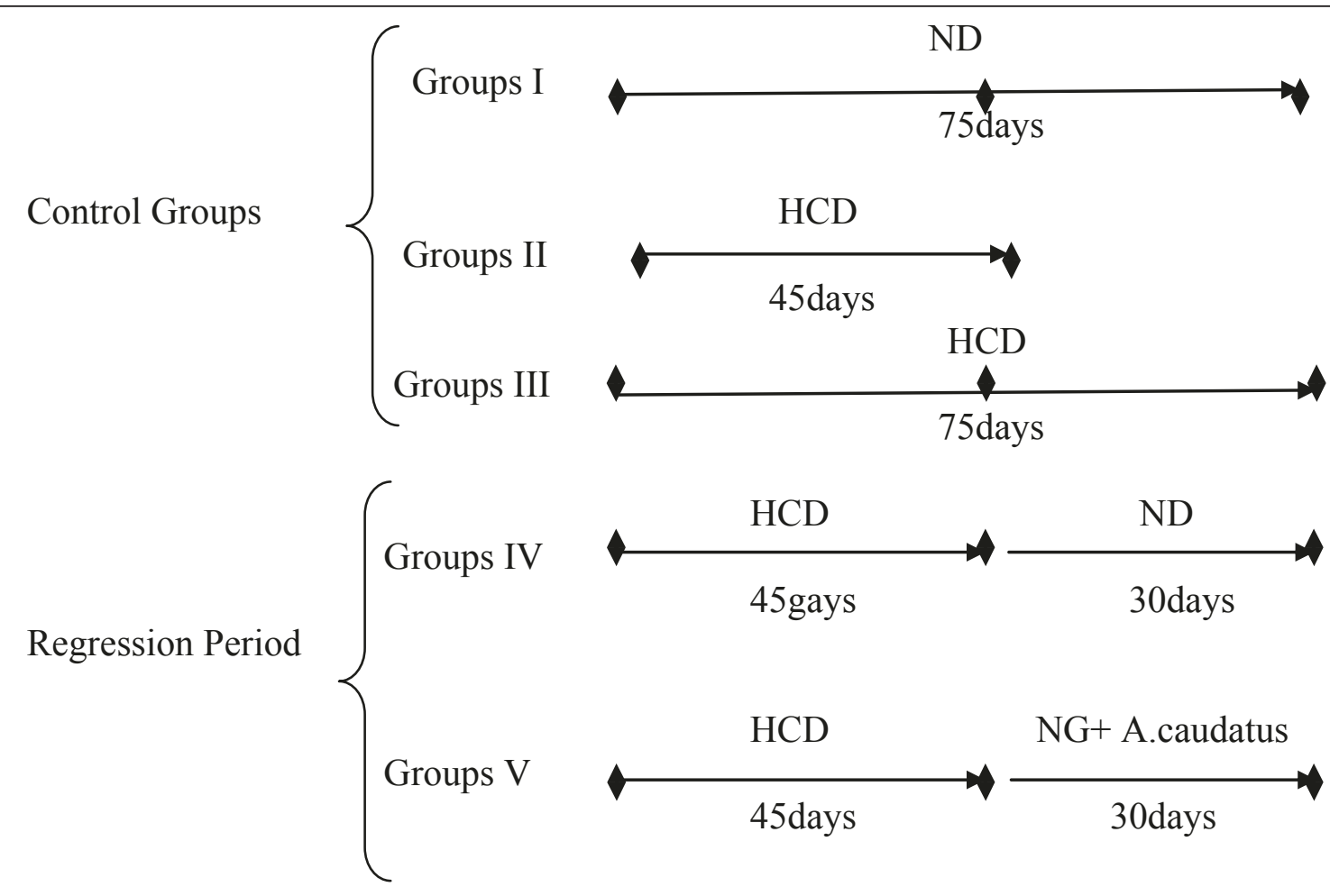

ND: Normal diet

HCD: Hypercholesterolemic diet

$\mathrm{ND}+$ A.caudatus: normal diet + A. caudatus $(150 \mathrm{mg} \cdot \mathrm{kg}$ day $)$

: Time of blood sampling

Figure 1 Scheme of the experimental regression period showing the days.

and the results were determined on a scale of 1-4 in relation to the thickness of media layer as follows:

- Grade 1. Plaque less than half as thick as the media with some form of endothelial dysfunction

- Grade 2: Plaque at least half as thick as media with accumulation of intracellular lipid, macrophages, and smooth muscle cells.

- Grade 3: Plaque as thick as the media with an abundance of macrophages, smooth muscle cells, and connective tissue.

- Grade 4: Plaque thicker than the media with a large intracellular intimal lipid core and inflammatory cell infiltration [27].

All histopathological evaluations were done by a pathologist blinded to the experimental design.

\section{Statistical analysis}

All values were expressed as mean \pm SD Significant differences among the groups were determined by one-way
ANOVA using the SPSS 13.0 software package program. Values of $\mathrm{p}<0.05$ were taken as statistically significant.

\section{Results}

Amount of flavenoids and anthocyanins

Each $100 \mathrm{~g}$ powder of A. caudatus results in $3.8 \pm 0.029$ g extract powder. The amount of total flavonoids based on hyperoside and anthocyanins in $100 \mathrm{~g}$ of $A$. caudatus extract is $0.379 \pm 0.02 \mathrm{~g}$ and $24.1 \pm 1.29 \mathrm{mg}$ respectively.

\section{Changes in biochemical parameters level in serum}

-At the onset, no significance was found between the mean values among the study groups. Keeping the rabbits on high cholesterol diet significantly increased Cho, TG, LDL-C, HDL-C, apoB, AI, CRP, MDA, OX-LDL and apoA in Groups II, III, IV and V on the $45^{\text {th }}$ days, as compared to Group I, However after the $75^{\text {th }}$ days in Groups III as compared to Group I (Table 1). 
Table 1 Effects of hydroalcoholic extract of $A$. caudatus on Selective biochemical parameters in rabbits fed with high cholesterol diets on $0,45^{\text {th }}$ and $75^{\text {th }}$ days

\begin{tabular}{|c|c|c|c|c|c|c|}
\hline $\begin{array}{l}\text { Biochemical } \\
\text { parameters }\end{array}$ & $\begin{array}{c}\text { Duration } \\
\text { (days) }\end{array}$ & Groupl & Groupll & GroupllI & GroupIV & GroupV \\
\hline & 0 & $41.4 \pm 8.443933$ & $47.6 \pm 7.436397$ & $46.8 \pm 7.463243$ & $45.4 \pm 8.792042$ & $45.8 \pm 6.723095$ \\
\hline & 45 & $46.8 \pm 7.463243$ & $898.2 \pm 84.3872$ & $664 \pm 192.3382$ & $786.2 \pm 180.7836$ & $876.8 \pm 100.3927$ \\
\hline \multirow[t]{3}{*}{ Cholesterol(m g/dl) } & 75 & $47.6 \pm 7.436397$ & -二-——-二-二 & $1053.2 \pm 34.76636$ & $1020.8 \pm 72.58237$ & $575 \pm 34.12477 \mathrm{ba}$ \\
\hline & 0 & $45.267 \pm 11.58879$ & $55.8 \pm 6.797058$ & $58.2 \pm 7.823043$ & $44.2 \pm 12.39758$ & $59 \pm 10.65364$ \\
\hline & 45 & $45.267 \pm 12.39758$ & $166.2 \pm 30.32656$ & $109.4 \pm 20.59854$ & $156.2 \pm 36.46505$ & $131.6 \pm 7.700649$ \\
\hline \multirow[t]{3}{*}{ Triglyceride (mg/dl) } & 75 & $46.233 \pm 1.16301$ & -——————— & $238.4 \pm 55.13892$ & $195.8 \pm 54.29273$ & $85.6 \pm 7.700649$ \\
\hline & 0 & $16.42 \pm 1.99925$ & $17.42 \pm 1.485598$ & $15.086 \pm 1.117578$ & $16.96 \pm 1.7358$ & $16.98 \pm 1.01341$ \\
\hline & 45 & $17.1 \pm 1.604681$ & $837.2 \pm 65.78146$ & $839.2 \pm 46.21904$ & $813.2 \pm 73.41117$ & $660.62 \pm 361.4526$ \\
\hline \multirow[t]{3}{*}{ LDL-cholesterol mg/dl) } & 75 & $17.38 \pm 1.070981$ & 二———-二-—- & $952.98 \pm 50.06078$ & $694.88 \pm 45.25231 b$ & $426.8 \pm 36.0236 \mathrm{~b}$ \\
\hline & 0 & $23.4 \pm 9.607289$ & $16.8 \pm 3.114482$ & $18.6 \pm 2.607681$ & $17.4 \pm 3.130495$ & $19.4 \pm 6.107373$ \\
\hline & 45 & $20.8 \pm 5.630275$ & $61.6 \pm 12.05404$ & $56.8 \pm 10.56882$ & $82 \pm 14.91643$ & $70.8 \pm 10.84896$ \\
\hline \multirow[t]{3}{*}{ HDL- cholesterol (mg/dl) } & 75 & $19 \pm 5.43139$ & -——-——-—— & $81.2 \pm 16.42255$ & $86.4 \pm 17.85497$ & $134.2 \pm 11.14451 \mathrm{ba}$ \\
\hline & 0 & $8.2 \pm 1.48324$ & $10.2 \pm 4.91935$ & $13.6 \pm 4.037326$ & $14.2 \pm 3.563706$ & $14.4 \pm 3.781534$ \\
\hline & 45 & $14 \pm 4.52769$ & $34.8 \pm 10.32957$ & $30 \pm 9.082951$ & $27 \pm 5.522681$ & $28.8 \pm 4.658326$ \\
\hline \multirow[t]{3}{*}{ apolipoprotein B (mg/dl) } & 75 & $9.8667 \pm 1.30384$ & -——-——-—— & $58.2 \pm 11.43241$ & $49.2 \pm 11.64903$ & $41 \pm 8.602325$ \\
\hline & 0 & $43 \pm 9.823441$ & $42.2 \pm 9.364828$ & $43.6 \pm 11.90798$ & $41.8 \pm 8.757854$ & $41.4 \pm 12.83745$ \\
\hline & 45 & $47.8 \pm 5.215362$ & $27.2 \pm 7.362065$ & $27.6 \pm 7.924645$ & $28.8 \pm 6.648308$ & $29.6 \pm 6.308724$ \\
\hline \multirow[t]{3}{*}{ apolipoprotein A (mg/dl) } & 75 & $34.8 \pm 8.288546$ & -——_-_- & $22.4 \pm 7.765307$ & $21 \pm 9.66954$ & $52.4 \pm 8.961027 \mathrm{ba}$ \\
\hline & 0 & $0.3 \pm 0.141421$ & $0.16 \pm 0.089443$ & $0.2 \pm 0.141421$ & $0.2 \pm 0.141421$ & $0.2 \pm 0.1$ \\
\hline & 45 & $0.2 \pm 1.604681$ & $0.7 \pm 0.070711$ & $0.68 \pm 0.164317$ & $0.64 \pm 0.151658$ & $0.7 \pm 0.070711$ \\
\hline \multirow[t]{2}{*}{ de Malondialdehy $(\mathrm{mol} / \mathrm{l})$} & 75 & $0.22 \pm 0.130384$ & -二-二————— & $1.7 \pm 0.234521$ & $0.92 \pm 0.204939 \mathrm{~b}$ & $0.35 \pm 0.070711 \mathrm{ba}$ \\
\hline & 0 & $3.02 \pm 0.141421$ & $3.66 \pm 1.934683$ & $2.26 \pm 1.062073$ & $2.66 \pm 1.825651$ & $2.32 \pm 1.634625$ \\
\hline \multirow[t]{4}{*}{ C-reactive protein (mg/l) } & 45 & $2.96 \pm 1.564609$ & $12.82 \pm 3.094673$ & $11.36 \pm 3.706481$ & $14.08 \pm 2.259867$ & $12.46 \pm 3.304996$ \\
\hline & 75 & $2.58 \pm 1.88202$ & -———————- & $23.4 \pm 3.361547$ & $8.9 \pm 0.514782 b$ & $5.1 \pm 1.031988 \mathrm{ba}$ \\
\hline & 0 & $15.12 \pm 1.41492$ & $15.26 \pm 1.209545$ & $15.22 \pm 1.243785$ & $15.72 \pm 2.667771$ & $14.46 \pm 1.209545$ \\
\hline & 45 & $16.22 \pm 2.615722$ & $23.32 \pm 2.963444$ & $23.32 \pm 3.013636$ & $25.72 \pm 4.130617$ & $26.12 \pm 3.62519$ \\
\hline \multirow[t]{3}{*}{ OX- LDL(ng/ml) } & 75 & $15.5 \pm 2.382226$ & -——-—-—— & $35.12 \pm 5.157713$ & $25.54 \pm 3.72599$ & $18.82 \pm 1.411382 b$ \\
\hline & 0 & $42.358 \pm 8.124376$ & $46.554 \pm 7.265138$ & $45.284 \pm 8.458223$ & $45.862 \pm 12.62378$ & $44.846 \pm 6.728988$ \\
\hline & 45 & $45.926 \pm 7.531051$ & $884.204 \pm 83.63083$ & $729.088 \pm 148.0296$ & $738.548 \pm 148.253$ & $867.5016 \pm 102.6377$ \\
\hline $\mathrm{Al}$ & 75 & $46.642 \pm 7.538247$ & -—-—-—-— & $1040.96 \pm 33.85897$ & $1011.03 \pm 26.33166$ & $551.062 \pm 71.06503 b$ \\
\hline
\end{tabular}

Group I: Fed with Normal diet (control group) (75 ${ }^{\text {th }}$ days)

Group II: Normal diet + cholesterol $\left(45^{\text {th }}\right.$ days)

Group III: Normal diet + cholesterol $\left(75^{\text {th }}\right.$ days)

Group IV: Normal diet + cholesterol for $45^{\text {th }}$ days and Normal diet for $30^{\text {th }}$ days

Group V: Normal diet + cholesterol for $45^{\text {th }}$ days and Normal diet $+A$. caudatus for $30^{\text {th }}$ days

b Significant difference between Group III with Groups IV Group V. ( $p<0.05)$

c Significant difference between Group IV with Group V. $(p<0.05)$

Cho: total cholesterol, TG:Triglyceride, LDL-C: LDL-cholesterol, HDL-C: HDL-cholesterol, ApoB:apolipoproteinB, ApoA:polipoproteinA, MDA: malondialdehyde,

CRP:C-reactive protein, Al: atherosclerosis index

In regression period dietary use of $A$. caudatus in Group V significantly decreased Cho, LDL-C, CRP, MDA, OX-LDL and AI in compared Group III on the $75^{\text {th }}$ days, whereas in this period in the group fed Normal diet (GroupIV) significantly decreased LDL-C, CRP and MDA in compared Group III on the $75^{\text {th }}$ days (Table 1).
During the regression, in the group fed with $A$. caudatus in addition to Normal diet (Group V) the levels of cho, LDL-C, MDA and CRP were found to be significantly decreased, whereas TG, apoB, AI and OX-LDL nonsignificantly decreased compared to the rabbits fed normal diet (Group IV), on the other hand, this diet the levels of apoA and HDLC significantly increased in compared Group IV (Table 1). 


\section{Aortic of atherosclerotic lesions}

The aorta atherosclerotic lesions of GroupI rabbits showed normal histology. However aortic of atherosclerosis of GroupII ( $45^{\text {th }}$ days) and GroupIII ( $75^{\text {th }}$ days) respectiv $(1.203 \pm 0.34356)$ and $(2.76 \pm 0.360555)$. The ratio of the atherosclerotic lesions area of the GroupIV $(1.266 \pm 0.416333)$ and GroupV $(086 \pm 0.503322)$ was significantly smaller $(\mathrm{p}<0.05)$ than that the GroupIII (table 2). The was a nonsignificant reduction in the aorta atherosclerotic rabbits fed on normal diet $+A$. caudatus for $30^{\text {th }}$ days (GroupV) compared with rabbits fed on normal diet for $30^{\text {th }}$ days(GroupIV), indicating that $A$. caudatus accelerated the regression of atherosclerotic lesions (Figure 2).

\section{Discussion}

The results presented above indicate that Amaranthus, has significant antihyperlipidemic and antiatherogenic effects and promoted the regression of atheromatous lesions. This was evidenced by decrease in the extent of accumulation of cholesterol and triglycerides in serum and aorta of rabbits to slow lipid peroxidation process (lower Ox-LDL and MDA), and finally to enhance the inflammatory response of the endothelial cells and accelerated the regression of atheromatous lesions in the aorta as evidenced by significantly low sudanophilic staining. Andrea et al. (2002), shows positive effect of $A$. caudatus extract to decrease of cholesterol level, LDL-C, VLDL-C and TG [19]. Recent studies has shown $A$. caudatus extract decreased the most important risk factors of cardiovascular diseases the serum lipoproteins, apoB and Ox-LDL and inflammatory factors prevented atherosclerosis [20]. Amaranthus have Certain particularly soluble fibers, which have a high water holding capacity, appear to be effective in lowering the serum levels of

Table 2 Comparison of atheroma plaque in aortic cuts of four groups of rabbits fed with high cholesterol diets

\begin{tabular}{lccc}
\hline Groups & $\begin{array}{c}\text { Plaque } \\
\text { thickness }\end{array}$ & $\begin{array}{c}\text { Plaque } \\
\text { stage }\end{array}$ & $\begin{array}{c}\text { Plaque thickness to } \\
\text { media thickness }\end{array}$ \\
\hline Groupll & $1.2 \pm 0.34356$ & 1 & $\begin{array}{c}\text { More than half of media } \\
\text { thickness }\end{array}$ \\
\hline Group III & $2.76 \pm 0.360555$ & 2 & $\begin{array}{c}\text { Plaque at least half as thick } \\
\text { as media }\end{array}$ \\
\hline Group IV & $1.26 \pm 0.416333^{\mathbf{a}}$ & 1 & $\begin{array}{c}\text { More than half of media } \\
\text { thickness }\end{array}$ \\
\hline Group V & $086 \pm 0.503322^{\text {a }}$ & 1 & $\begin{array}{c}\text { More than half of media } \\
\text { thickness }\end{array}$ \\
\hline
\end{tabular}

Group II: Standard diet + cholesterol ( $75^{\text {th }}$ days)

Group III: Standard diet + cholesterol ( $45^{\text {th }}$ days)

Group IV: Standard diet + cholesterol for $45^{\text {th }}$ days and Standard diet for $30^{\text {th }}$ days

Group V: Standard diet + cholesterol for $45^{\text {th }}$ days and Standard diet $+A$. caudatus for $30^{\text {th }}$ days

aSignificant difference between Group V and Group IV with Groupll. $(p<0.05)$ total and LDL cholesterol in both normal and hyperlipidemic subjects [28]. Among the dietary interventions, dietary fibers play a crucial role in lipid lowering [29]. The effect of dietary fiber on cholesterol metabolism has been studied extensively. These effects are associated with increased excretion of bile acids and neutral sterols, increased catabolism of cholesterol, and reduced absorption of cholesterol and fat [30]. Squalene is an intermediate in cholesterol biosynthesis acts as a hyocholesterolemic agent by inhibiting HMG-CoA reductase, a necessary enzyme in cholesterol biosynthesis [17].

Atherosclerosis is widely viewed as an inflammatory disease [31]. Therefore, the reported inverse association between fruits and vegetable consumption(eight vs. two servings/day) and the selected proinflammatory gene expression and significantly reduced CRP levels [32,33]. The anti-inflammatory mechanisms related to fruit and vegetable consumption are still unclear. Fruits and vegetables also are important sources of dietary fiber [34], contain several flavonoids and carotenoids with recognized antioxidant properties which appears to have an anti-inflammatory role flavonoids and carotenoids, by an inhibition of $\mathrm{NF} \kappa \mathrm{B}$ activity, through suppressing the activation-related phosphorylation, and inhibiting the nuclear translocation [34,35]. Also, dietary fiber intake could participate in weight control and favor weight loss, hypoglycemic actions and hypolipidemic effects [36].

The flavanols and anthocyanins, and their role in the modulation or reduction of risk factors and the prevention of cardiovascular health problems through different aspects of bioeficacy in vascular health platelet agregation, atherosclerosis, blood pressure, antioxidant status, inflammation-related markers, etc.) are consistent. Anthocyanins seem to have a clear effect on endothelial function and myocardium protection [37], Anthocyanins have an effect on cholesterol distribution, protecting endothelial cells from CD40- induced proinflammatory signalling [38]. In macrophages, blackberry anthocyanins inhibit LPS induced nitric oxide biosynthesis [39]. Anthocyanins have anti inflammatory and free radical scavenging activity [39]. A great number of studies have shown that, anthocyanins prevents endothelial damages and act as an inhibitor of endothelial cell death $[39,40]$. Anthocyanins protect endothelial cell by inhibition peroxynitrites that it leads to oxidative damages [39]. The mechanism by which the Amaranthus reduces atheromatous lesion formation and accelerates the rate of lesion regression has not been examined in detail. The hypolipidemic action of the Amaranthus contributes to this. Although the mechanism of the antiinflammatory effect is not clear, the antiinflammatory effect as evidenced by a decrease in inflammatory markers such as 


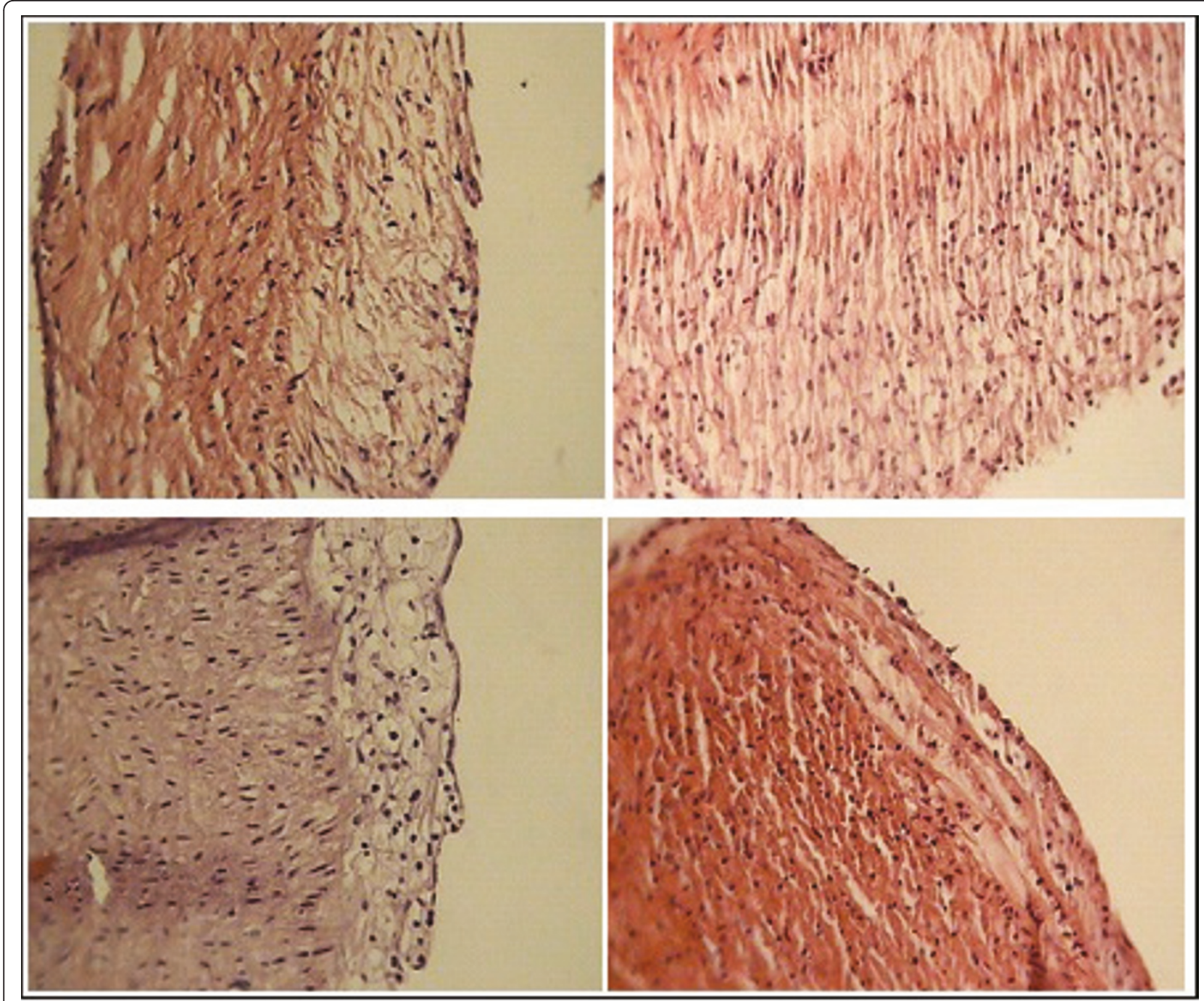

Figure 2 Histology of aorta and grade of atherosclerotic plaque in studied groups. a: Normal diet + cholesterol (45 $5^{\text {th }}$ days) b: Normal diet + cholesterol ( $75^{\text {th }}$ days) c: Normal diet + cholesterol for $45^{\text {th }}$ days and Normal diet for $30^{\text {th }}$ days $d$ : Normal diet + cholesterol for $45^{\text {th }}$ days and Normal diet + A. caudatus for $30^{\text {th }}$ days.

CRP may also contribute to the protective effect stress oxidative.

\section{Conclusion}

The objectives of the present investigation were Amaranthus produces regression of hypercholesterolemic atherosclerosis and regression is associated with reductions in serum lipids and oxidative stress. An investigation was therefore made of the effects of Amaranthus on the regression of atherosclerosis and serum lipids (cholesterol, triglyceride and LDL-cholesterol, HDL-C, Apolipoprotein $B(a p o B)$, apolipoprotein $A(a p o A)$, malondialdehyde (MDA), hs-C-reactive protein (hs-CRP) as well as atherosclerosis index (AI) and OX-LDL in rabbits. Oxidative stress parameters were assessed by measuring serum malondialdehyde (MDA) an index of levels of oxygen radicals, aortic antioxidant reserve and the oxygen radical-producing activity of white blood cells cells (WBC-CL). Our studies indicate that Amaranth can be considered as an effective natural antioxidant supplement capable of protecting cellular membranes against oxidative.

\section{Acknowledgements}

The work was supported by a grant number 84143 from Isfahan

Cardiovascular Research Center (ICRC). We would like to thank Isfahan Cardiovascular Research Center and staff of ICRC Basic Science Laboratory

\section{Author details}

'Department of Biology, Faculty of Sciences, Isfahan University, Isfahan, Iran. ${ }^{2}$ Isfahan Cardiovascular Research Center, Applied Physiology Research Center, 
Isfahan University of Medical Sciences, Isfahan, Iran. ${ }^{3}$ Department of Biology, Izeh Branch, Islamic Azad University, Izeh, Iran.

\section{Authors' contributions}

NK Participated in the study design of study, interpretation of results, wrote the manuscript and proof read paper and made changes. SA designed and organized the research, contributed wrote the manuscript and proof read paper and made changes. MS contributed with the conception and design. All authors: read and approved the final manuscript.

\section{Competing interests}

The authors declare that they have no competing interests.

Received: 19 February 2011 Accepted: 28 May 2011

Published: 28 May 2011

\section{References}

1. Stary HC: Atlas of Atherosclerosis: Progression and Regression. New York. NY: The Parthenon Publishing Group; 2003.

2. Armstrong ML, Megan MB: Lipid depletion in atheromatous coronary arteries in rhesus monkeys after regression diets. Circ Res 1972, 30:675-680.

3. Tsukamoto K, Tangirala R, Chun SH, Puré E, Rader DJ: Rapid regression of atherosclerosis induced by liver-directed gene transfer of apoE in apoEdeficient mice. Arterioscler Thromb Vasc Biol 1999, 19:2162-2170

4. Kane JP, Malloy MJ, Ports TA, Phillips NR, Diehl JC, Havel RJ: Regression of coronary atherosclerosis during treatment of familial

hypercholesterolemia with combined drug regimens. J Am Med Assoc 1990, 264:3007-3012.

5. Helft G, Worthley SG, Fuster V, Fayad ZA, Zaman AG, Corti R, Fallon JT, Badimon JJ: Progression and regression of atherosclerotic lesions. Monitoring with serial noninvasive magnetic resonance imaging. Circulation 2002, 105:993-998

6. Nissen SE, Tsunoda T, Tuzcu EM, Schoenhagen P, Cooper CJ, Yasin M, Eaton GM, Lauer MA, Sheldon WS, Grines CL, Halpern S, Crowe T, Blankenship JC, Kerensky R: Effect of recombinant apoA-I Milano on coronary atherosclerosis in patients with acute coronary syndromes. A randomized control trial. J Am Med Assoc 2003, 290:2292-2300.

7. Robert L, Raffai Samuel M, Loeb, Karl H: Weisgraber. Apolipoprotein E Promotes the Regression of Atherosclerosis Independently of Lowering Plasma Cholesterol Levels. Arterioscler Thromb VasC Biol 2005, 25:436-441.

8. Oka K, Chan L: Inhibition and regression of Atheroscleotic lesions. Acta Biochim Pol 2005, 52(2):311-319.

9. Frisinghelli A, Mafrici A: Regression or reduction in progression of atherosclerosis, and avoidance of coronary events, with lovastatin in patients with or at high risk of cardiovascular disease: a review. Clin Drug Investig 2007, 27(9):591-604.

10. Prasad K: Regression of hypercholesterolemic atherosclerosis in rabbits by secoisolaricresinol diglucoside isolated from flaxseed. Atherosclerosis 2008, 197:34-42.

11. Prasad K: A study on regression of hypercholesterolemic atherosclerosis in rabbits by Flax Lignan complex. J Cardiovasc Pharmacol Ther 2007, 12:304.

12. Amensour M, Sendra E, Abrini J, Bouhdid S: Total phenolic content and antioxidant activity of myrtle (Myrtus communis) extracts. Nat Prod Commun 2009, 4(6):819-24

13. Sengupta A, Ghosh M: Modulation of platelet aggregation, haematological and histological parameters by structured lipids on hypercholesterolemic rats. Lipids 2010, 45:393-400.

14. Martirosyan DM: Amaranth as a nutritional supplement for the modern diet. In Amaranth Legacy. Volume 14. USA; 2001:2-4.

15. Martirosyan DM: Amaranth, quinoa and lentils as a source of modern diet and functional foods. I book: Non-traditional natural resources, innovation technologies and products Moscow, Russia, Russian Academy of Natural Sciences. 2001, 91-100.

16. Kadoshnikov Sergey I, Kadoshnikova Irina G, Martirosyan Danik M: Investigation of Fractional Composition of the Protein in Amaranth. Book "Non-Traditional Natural Resources Innovation Technologies and Products" Moscow, Russian Academy of Natural Sciences. Moscow; 2005, 12: 81-104.
17. Tikekar RV, Ludescher RD, Karwe MV: Processing stability of squalene in Amaranth and antioxidant potentioa of Amaranth extract. J Agric Food Chem 2008, 56:10675-10678.

18. Heinz SA, Henson DA, Nieman DC, Austin MD, Jin F: A 12- week supplementation with quercetin does not affect natural killer cell activity, granulocyte oxidative burst activity or granulocyte phagocytosis in female human subjects. J of Nutrition 2010, 1-9.

19. Andrea YA, Plate JA: Cholesterol-lowering effect of extruded amaranth (Amaranthus caudatus L.). Food Chemistry 2002, 76:1-6.

20. Kabiri N, Asgary S, Madani H, Mahzuni P: Effects of Amaranthus caudatus L. extract and lovastatin on atherosclerosis in hypercholesterolemic rabbits. J of Medicinal Plants Research 2010, 4(5):355-361.

21. Qureshi AA, Qureshi N, Wright JK, Shen Z, Kramer G, Gapor A, et al: Lowering of serum cholesterol in hyperchlesterolemic humans by tocotrienols (palmvitee). American Journal of Clinical Nutrition 1991, 53:1021-1026.

22. Yu SG, Thomas AM, Gapor A, Tan B, Qureshi N, Qureshi AA: Dose-response impact of various tocotrienols on serum lipid parameters in 5-week-old female chickens. Lipids 2006, 41(5):453-61.

23. Eseyin $\mathrm{O}$, Ebong $\mathrm{P}$, Igboasoiyi $\mathrm{A}$, Oforah E: Hypoglycemic effect of the seed extract of Telfairia occidentalis in rat. Pakistan Journal of Biological Sciences 2007, 10(3):498-501.

24. Petry RD, Ortega GG, Silva WB: Flavonoid content assay: influence of the reagent concentration and reaction time on the spectrophotometric behavior of the aluminium chloride-flavonoid complex. Pharmazie 2001, 56(6):465-70

25. Francis FJ: Anthocyanins as food colors. New York: Academic Press; 1982, 181-207.

26. Zou Y, Lu Y, Wei D: Hypocholesterolemic effects of a flavonoid-rich extract of Hypericum perforatum L. in rats fed a cholesterol-rich diet. J Agric Food Chem 2005, 53(7):2462-6.

27. Chekanov VS: Low frequency electrical impulses reduce atherosclerosis in cholesterol fed rabbits. Med 2003, 9(8):BR302-9.

28. Fernandez ML: Soluble fiber and nondigestible carbohydrate effects on plasma lipids and cardiovascular risk. Curr Opin Lipidol 2001, 12:35-40.

29. Boban PT, Nambisan B, Sudhakaran PR: Dietary mucilage promotes regression of atheromatous lesions in hypercholesterolemic rabbits. Phytother Res 2009, 23:725-730.

30. Talati R, Baker WL, Pabilonia MS, Wbite CM, Coleman Cl: The effects of barley-derived soluble fiber on serum lipids. Annals of Family Medicine 2009, 7(2):157.

31. Estruch R, Martinez-Gonzalez AM, Corella D, Salvado JS, Gutierrez VR, Covas ML, et al: Effect of a Mediterranean-style diet on cardiovascular risk factors. Ann Intern Med 2006, 145:1-11.

32. Watzl B, Kulling SE, Möseneder J, Barth SW, Bub A: A 4-wk intervention with high intake of carotenoid-rich vegetables and fruit reduces plasma C-reactive protein in healthy, nonsmoking men. Am J Clin Nutr 2005 , 82(5):1052-8.

33. Hermsdorff HH, Zulet MA, Puchau B, Martínez JA: Fruit and vegetable consumption and proinflammatory gene expression from peripheral blood mononuclear cells in young adults: a translational study. Nutr Metab (Lond) 2010, 7:42, 13.

34. Crujeiras AB, Parra MD, Rodríguez MC, Martínez de Morentin BE, Martínez JA: A role for fruit content in energy-restricted diets in improving antioxidant status in obese women during weight loss. Nutrition 2006, 22(6):593-9.

35. Holt RR, Lazarus SA, Sullards MC, Zhu QY, Schramm DD, Hammerstone JF, Fraga CG, Schmitz HH, Keen CL: Procyanidin dimer B2 in human plasma after the consumption of a flavanol-rich cocoa. Am J Clin Nutr 2002, 76:798-804.

36. Galisteo M, Duarte J, Zarzuelo A: Effects of dietary fibers on disturbances clustered in the metabolic syndrome. J Nutr Biochem 2008, 19(2):71-84.

37. Pascual-Teresa S, Moreno DA, García-Viguera C: Flavanols and Anthocyanins in Cardiovascular Health: A Review of Current Evidence. J Mol Sci 2010, 11(4):1679-1703.

38. Xia M, Ling W, Zhu H, Wang Q, Ma J, Hou M, Tang Z, Li L, Ye Q: Anthocyanin prevents CD40-activated proinflammatory signaling in endothelial cell by regulating cholesterol distribution. Arterioscler. Thromb. Vasc Biol 2007, 27:519-524. 
39. Pergola C, Rossi A, Dugo P, Cuzzocrea S, Sautebin L: Inhibition of nitric oxide biosynthesis by anthocyanin fraction of blackberry extract. Nitric Oxide 2006, 15(1):30-9.

40. Borradaile NM, Dreu LE, Barrett PHR, Huff MW: Inhibition of hepatocyte apoB secretion by naringenin: enhanced rapid intracellular degradation independent of reduced microsomal cholesteryl esters. J Lipid Res 2002, 43(9):1144-1154

doi:10.1186/1476-511X-10-89

Cite this article as: Kabiri et al:: Lipid lowering by hydroalcoholic extracts of Amaranthus Caudatus $L$. induces regression of rabbits atherosclerotic lesions. Lipids in Health and Disease 2011 10:89.

Submit your next manuscript to BioMed Central and take full advantage of:

- Convenient online submission

- Thorough peer review

- No space constraints or color figure charges

- Immediate publication on acceptance

- Inclusion in PubMed, CAS, Scopus and Google Scholar

- Research which is freely available for redistribution

Submit your manuscript at www.biomedcentral.com/submit
Ciomed Central 